\begin{tabular}{|l|l|l||}
\hline \multicolumn{2}{|c|}{ PublisherInfo } \\
\hline \hline PublisherName & $:$ & BioMed Central \\
\hline \hline PublisherLocation & $:$ & London \\
\hline \hline PublisherImprintName & $:$ & BioMed Central \\
\hline \hline
\end{tabular}

\title{
Protecting plants
}

\begin{tabular}{||l|l|l||}
\hline \multicolumn{2}{|c||}{ ArticleInfo } \\
\hline \hline ArticleID & $:$ & 3850 \\
\hline \hline ArticleDOI & $:$ & $10.1186 /$ gb-spotlight-20001204-02 \\
\hline \hline ArticleCitationID & $:$ & spotlight-20001204-02 \\
\hline \hline ArticleSequenceNumber & $:$ & 287 \\
\hline \hline ArticleCategory & $:$ & Research news \\
\hline \hline ArticleFirstPage & $:$ & 1 \\
\hline \hline ArticleLastPage & $:$ & 2 \\
\hline \hline & $:$ & RegistrationDate : 2000-12-04 \\
ArticleHistory & $:$ & OnlineDate $: 2000-12-04$ \\
\hline \hline ArticleCopyright & $:$ & BioMed Central Ltd2000 \\
\hline \hline ArticleGrants & $:$ & \\
\hline \hline ArticleContext & $:$ & 130591111 \\
\hline \hline
\end{tabular}




\section{William Wells}

Email: wells@biotext.com

Plants that recognize a pathogen induce both a local defense response and a long-lasting, broad spectrum disease resistance throughout the plant, termed systemic acquired resistance (SAR). In the December Nature Genetics Maleck et al. use microarrays to monitor transcriptional changes during development of SAR (Nat Genet 2000, 26:403-410). Of the 10,000 expressed sequence tags (ESTs) on the microarrays, representing 25-30\% of all genes from Arabidopsis thaliana, 413 show changes of 2.5 -fold or more in at least two samples. Clustering of these results is aided by the use of multiple inducers and multiple genotypes. One cluster of 45 ESTs contains the SAR marker PR-1. All 26 available promoters in this cluster contain at least one binding site for the plant-specific WRKY transcription factors, suggesting a possible method by which these genes are co-regulated.

\section{References}

1. Nature Genetics, [http://www.nature.com/ng/]

2. Analysis of telomere lengths in cloned sheep.

This PDF file was created after publication. 